is to provide access to online resources useful for political science research and teaching. It is largely an umbrella gopher, providing links to other gopher servers where the documents are actually maintained. Documents maintained at the site of the APSA gopher server will include those of general interest to the discipline (e.g., conference programs) or those which are not accessible elsewhere.

The current main menu of the APSA gopher server is as follows:
About the American Political Science Association Gopher
American Government Gopher at Northwestern University
Comparative Politics
International Relations
Political Theory
Computers, Software, \& Data
The Political Science List of Lists
Conference Information
Scholarships and Fellowships
Related Gophers and Reference Information

The APSA gopher server is still in the developmental stage-expect new items and updated documents in the near future. It has nevertheless already become quite popular as a political science resource and is averaging over 100 log-ins per day.

The APSA gopher server is designed to work in conjunction with the Political Science Research and Teaching List (psrt-1) which itself has 1100 subscribers in 34 countries. PSRT-L is a Listserv discussion group (send the command "subscribe psrt-l your name" to listserv@missou1.missouri.edu to join).

Remember, as you explore the menu items in the APSA gopher, that you may be viewing menus and accessing documents stored anywhere in the world. Please direct your feedback on the contents of individual items on the gopher to the appropriate site. Inquiries relevant to political science research and teaching as well as short announcements and abstracts of other documents should be sent to the list (psrt-1@missou1.missouri.edu) for distribution to other participants. Long documents and any archival material (examples include conference programs, writing of more than a few paragraphs, data, reference material, etc) should be placed on the APSA gopher.

We are looking for new materials for the APSA gopher. In particular we would like to list conference announcements, calls for papers, and the like on the gopher, as well as to link to other relevant gophers. Bill Ball is the general coordinator of the APSA gopher project. Please contact him with general questions and comments at ball@trenton.edu or (609) 771-2747; or contact Michael Brintnall at APSA at incem024@sivm.si.edu or (202) 483-2512. If you know of resources that should be considered for the gopher, or wish to volunteer to assist in its management, please also contact Bill Ball or Michael Brintnall.

\section{Research Support Grants Announced}

The APSA Research Support Committee recently made 13 awards totaling $\$ 15,000$ under APSA's program to support research by political scientists outside of Ph.D.-granting, research institutions. These awards are supported entirely by Association general revenues - that is, by member dues-as one of the many facets of the Association's commitment to assuring scholarly opportunities for all.

APSA Research Support Awards are merit-based and this year include studies of the suffragists and the idea of women's political leadership, the oversight of the CIA in $1947-70$, argument in agenda transformation on the Supreme Court, partisanship and vote decision in the 1992 Presidential election, gender politics, and nuclear and hightechnology conventional weapons. The committee received 32 proposals.

The Research Support Committee is chaired by John Sprague, Washington University, and includes Charles W. Harris, Howard University; Margaret Karns, University of Dayton; Kathleen Knight, University of Houston; Stanley Rothman, Smith College; and
Karen O'Connor, Emory University.

The grant recipients are David $\mathrm{M}$. Barrett, Villanova University, "Senator Richard Russell and Congressional Oversight of the Central Intelligence Agency, 1947-1970"; Barbara C. Burrell, University of Wisconsin-Extension, "Connections: the Suffragists and the Idea of Womens Political Leadership"; Paula M. Fleming, California State University, "Power vs Frame: When Do States Take Risks?"; Katy J. Harriger, Wake Forest University, "The Role of Argument in Agenda Transformation on the Supreme Court"; James G. Leibert, Dickinson State University, "A Multivalued Examination of Parisanship and Vote Decision in the 1992 Presidential Election"; Amy G. Mazur, Indiana UniversityPurdue, "Comparative State Feminism: the Case of France"; Gary Prevost, St Johns University, “Social Movements and the Future of Spanish Social Democracy"; Mark J. Rozell, Mary Washington College, "The Christian Right in the Republican Party: Holy Alliance or Marriage of Convenience"; Anne Sisson Runyan, SUNY-Potsdam, "Gender Politics and the New World Order: An Examination of Feminist Responses to the European Community and the North American Free Trade AgreementInternational Feminism, Feminist Internationalism, or Feminist Internationalization"; George E. Shambaugh, Smith College, "Dominance, Dependence and Political Power: Controling Nuclear and High Technology Conventional Weapons Proliferation in the PostCold War Era"; Robert R. Thompson, Beaver College, “A Bulldog Among Spaniels. John Quincy Adams and the Genesis of RussianAmerican Relations, 1809-1814"; Luann K. Troxel, Smith College, "Women and Political Power in the New East Europe: Is There a Difference"; Craig M. Wheeland, Villanova University, "Council Evaluation of the City Manager's

Performance."

If you would like more information on APSA's research grants or have suggestions for the committee, please contact Michael Brint- 
nall at APSA. The 1995 competition will be announced in the December issue of $P S$.

\section{Advisory Opinion from Ethics Committee on Notification of Job Applicants When Positions Are Filled}

The APSA Committee on Professional Ethics, Rights and Freedoms has issued an Advisory Opinion stating that it is good professional practice to notify job applicants when a position has been filled. This statement will be added to APSA's Open Listing Policy regarding announcement of job openings. The Open Listing Policy is part of the APSA Guide to Professional Ethics in Political Science and it is printed in each issue of the Personnel Service Newsletter.

The policy, with the new statement italicized for emphasis, is as follows:

\section{Open Listing Policy.}

It is a professional obligation of all political science departments to list in the APSA Personnel Service Newsletter all positions for which they are recruiting at the Instructor, Assistant, and Associate Professor levels. In addition, the listing of openings at the Full Professor level are strongly encouraged. It is also a professional obligation for departments to list temporary and visiting positions. Good professional practice and courtesy also calls for applicants to be notified when a position is filled.

The Committee on Professional Ethics, Rights and Freedoms is chaired by John J. DiIulio of the Woodrow Wilson School, Princeton University. Other current members are Jean Elshtain, Vanderbilt University, Joseph Silver, University System of Georgia, Janna Merrick, University of South Florida,

Michael E. Brint, Kenyon College, and Robert Montjoy, Auburn University. Contact Michael Brintnall at APSA with questions about the above policy or the work of the Committee on Professional Ethics, Rights and Freedoms.

\section{APSA Organized Section News}

Last spring, the organized section on Applied Political Science conducted a mail survey of section members and potential members concerning how their interests can best be served within the Association. While there was considerable support for remaining a separate section rather than disbanding or merging with a related section (the favorite for this alternative was Public Policy), this will not be possible under rules adopted by the Council in 1993 unless the membership increases to at least 250 (or about double the current level) before the spring of 1995. Applied political scientists, currently nonmembers of the section, are encouraged to join before December 31,1994 . They may do so by submitting $\$ 5$ to the APSA, c/o Michael Brintnall, 1527 New Hampshire Ave., N.W., Washington, D.C. 20036. For further information, please contact the section head, Bill Bacchus, Room 3726 N.S., U.S. Agency for International Development, Washington, D.C. 20523; 202-736-4014 (fax: call first); or the Treasurer, Howard Silver, COSSA, 1522 K St. N.W., Washington, D.C. 20036; 202-842-3525 (fax 202-842-2788).

\section{Verba Appoints Katzenstein and Katzenstein 1995 Program Chairs}

APSA President-Elect Sidney Verba, Harvard University, has appointed Mary Fainsod Katzenstein and Peter J. Katzenstein, Cornell University, to be the 1995 program chairs. The 1995 annual meeting will be held at the Chicago Hilton and Towers, August 31 through September 3, 1995, in Chicago, Illinois.

Katzenstein and Katzenstein have selected as their theme for the 1995 meeting "Liberalism at Century's End: Competing Perspectives." The relationship between the theme and the program's 46 divisions is described in the "Call

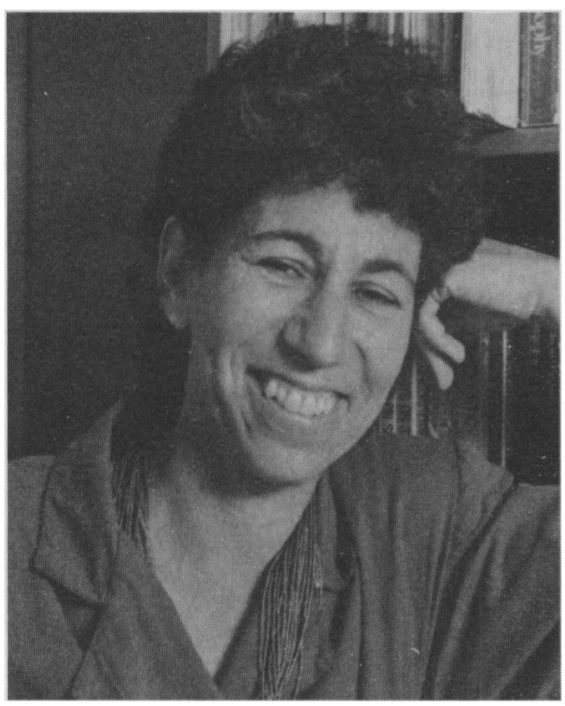

Mary Fainsod Katzenstein

for Papers" appearing elsewhere in this issue of $P S$.

Katzenstein and Katzenstein encourage wide participation in the 1995 program. The program chairs have introduced a new approach to organizing the program, recognizing the increasing size and complexity of the annual meeting. The chairs have developed submission forms for paper, panel, and roundtable proposals. The forms and detailed participation guidelines appear in this issue of $P S$. Please copy and use the forms when submitting proposals to division chairs.

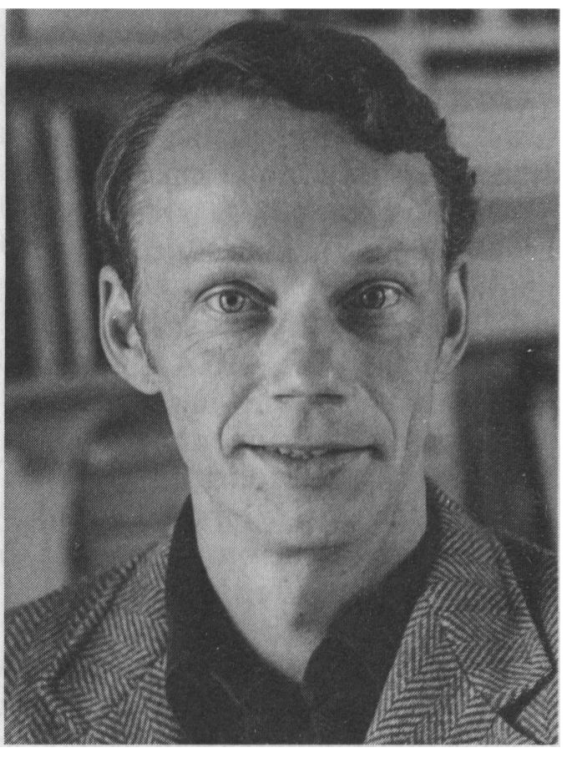

Peter J. Katzenstein

(Photo by Charles Harrington) 